\title{
PROYECCIÓN DE UN PERSONAJE EN CARPENTIER
}

\section{Manuel Laurentino Suárez}

Comúnmente en la producción de cada autor se vislumbran motivos que él utiliza para establecer su pensamiento. Esos motivos que al principio de su obra literaria se proyectan débilmente, le sirven para darle madurez como escritor mientras que su creación adquiere cierto valor literario. Tal es la situación con la figura del estudiante en un número de trabajos de Alejo Carpentier. El propósito de esta ponencia es trazar el desarrollo de este carácter en El camino de Santiago, y cómo evoluciona posteriormente en El recurso del método. Se tratará de analizar el papel que este personaje desempeña en la visión que el escritor cubano tiene del ser humano.

Juan de Amberes, el protagonista de El camino de Santiago, aparece en Flandes, frente a la mar, meditando junto a una rata pestilenta, lo que representa para él un mal presagio.

Este arrojado soldado de los tercios españoles al cavilar sobre el repelente roedor, comienza a analizar las posibilidades del contagio bubónico, y rápidamente pierde su osadía. A pesar de no haber contraído la enfermedad, Juan siente los síntomas y hace el comentario de "que la muerte sería buen castigo por haber dejado la enseñanza de los cantos que se destinan a la gloria de Nuestro Señor, para meterse a tambor de tropa. .."1 Se nota fácilmente que la enfermedad es más bien de carácter psicológico, y son sus pensamientos los que le perturban a causa de la psicosis de culpabilidad que se ha apoderado de su ser. Pero el deseo del protagonista como representante del hombre en general, no es el de la recuperación espiritual que ha de obtenerse con el arrepentimiento y la vuelta a la religión, sino que reside en la recuperación física. Aferrado a esta idea el hombre trata de engañar al Señor: "Juan había gimoteado todo aquello del pecho abrasado y de las bubas hinchadas, para que Dios, compadecido de quien se creía enfermo, no le mandara cabalmente la enfermedad" (20). Después de la horripilante frialdad que le estremece hasta el alma, y de tener una pesadilla con el Duque de Alba, decide tomar una nueva senda que le encamine a la vida espiritual. Es esa visión la que le conduce a trocar la espada por los cantos religiosos para abrazar " ${ }_{j} E l$ Camino de Santiago!" (23).

A partir del momento de la conversión, la vida del soldado oscilará entre los sentimientos religiosos y la apetencia mundana. Durante la peregrinación hacia la tumba del Santo, Juan va olvidando la promesa hecha al apóstol. El contacto con el agua en Bayona, le hace sentirse como un nuevo hombre, que se aproxima a los goces terrenales más que a los espirituales, y empieza a ver el vino como producto de embriaguez y no 
como el símbolo de la sangre de Cristo. El Camino de Santiago sigue frente a él, pero ya va perdiendo la atracción que éste poseía cuando se sentía moribundo y creía que la plaga se había apoderado de su cuerpo. Esto es natural, pues Juan, no es más que el reflejo de toda la humanidad, y el ser humano es más piadoso ante la proximidad de la muerte. Su vida no dejará de ser un constante dilema, pues la dualidad del hombre, carne y espíritu, se hallarán en continuo choque. Cuando se encuentra en Burgos, el cambio ha sido total, y se le ve de nuevo en el medio ambiente terrenal: juergas, mujeres y vino. Juan remata la noche con una moza que le "acoge en su cama hasta mañana, a cambio del permiso de besar las santas veneras que comienzan a descoserse de su esclavina" (42).

Decide encaminarse hacia las Indias. ${ }^{2}$ Otra vez enfermo, en medio de unas fiebres que le absorven la mente, Juan "reza, gime, araña la santa madera, se retuerce en el suelo como un exorcizado, implorando que le dejen entrar. ‘ $¡$ Santiago!' - solloza” (82).

Este hombre busca la renovación de los votos que realizó en Flandes, promesas que en realidad no hizo para restablecer su salud espiritual, sino que emprendió con el propósito de rehabilitarse físicamente. Juan seguirá alternando entre los dos caminos simbólicos: el sendero espiritual que le conduciría a la salvación eterna y el sendero terrenal de orientación epicuriana, él los cambia de acuerdo con la conveniencia del momento. También hay cierta semejanza con el don Juan de Tirso pues su actitud hacia la religión es una conveniencia, y esto bien se nota en las conocidas líneas de "tan largo me lo fiáis".

Es importante destacar que a pesar de haberse iniciado el protagonista como un colegial de música eclesiástica, Carpentier le coloca como estudiante picaresco que se desenvuelve dentro del ambiente estudiantil de la Imperial Universidad de San Ildefonso. Posiblemente el autor trate de crear la imagen del hombre como un estudiante asiduo que tiene propensidad a "las artes del Cuadrivio, con el conocimiento de las cifras para tañer la tecla, el arpa y el vihuela..."(76). Esta progresión de cambios que lleva a cabo la figura central es un recurso mediante el cual se propone la idea de que esta constante rotación es lo que hace que el peso de la cruz diaria sea más aceptable, así pues vemos a Juan en diferentes planos, como estudiante, como soldado, como peregrino y como aventurero.

Es en El recurso del método donde está mejor desarrollada la figura del estudiante, al menos dentro del plano político. Esta novela es una ambiciosa tentativa donde el escritor pretende hacer una cuidadosa investigación en relación con las dictaduras y la constante repetición de éstas en numerosos países. Este Primer Magistrado $\sin$ faz, que se encuentra a lo largo de las nebulosas páginas de la novela, es un sátrapa cuya manera de actuar es conocida universalmente. También representa al hombre poderoso de ayer, de hoy, $\mathrm{y}$ de mañana.

En esta narración el escritor explica muy hábilmente, por medio de su acostumbrado uso de numerosas imágenes, el significado de dictadura y de revolución. Carpentier da a entender, a través del desarrollo de los acontecimientos, que toda revolución que derroca a un gobierno, ya sea de base militar o popular, es el fin pero también el principio de toda dictadura. Es imposible rechazar la idea de que el autor ha tratado de captar el mundo político y su inestabilidad histórica, abarcando muy sutilmente los dos fenómenos que le componen. El narrador no modela solamente esas dos imágenes y el modo en que 
opera el trueque, sino que traza con auténtica persistencia la formación del hombre poderoso cuya germinación es llevada a cabo por el personaje estudiantil. Esto se expresa en las palabras del Primer Magistrado cuando le dice al estudiante quien será la persona que le substituirá: "¿Tú vendrías a ocupar mi puesto, no es cierto? "3 Una vez que la situación le sea propicia, el estudiante tomará las riendas y reemplazará al magistrado, creando así un ciclo que se repetirá constantemente.

Este círculo vicioso representa la inagotable fuente de donde manan estos hombres que manufacturan los escenarios políticos ante la humanidad espectadora que contempla el horrendo espectáculo una y otra vez. De manera que se puede afirmar que el novelista trata de moldear la figura del estudiante como la del individuo que florece y se desenvuelve conscientemente hasta llegar al punto de convertirle en el hombre usurpador de las libertades humanas. Para reafirmar la tipificación de este carácter es necesario recalcar una serie de motivos que el autor entreteje a lo largo de la obra. Se debe citar el hecho de que el estudiante llega al extremo de perder su individualidad, asi que cuando el secretario Peralta platica con el Primer Magistrado sobre el joven revolucionario, no le viene a la mente el nombre exacto del chico: "de apellido Álvarez, o Álvaro, o Álvarado. .. , más conocido por El Estudiante desde que, en un discurso particularmente agresivo, hubiese dicho: 'No vean en mi sino un estudiante más, cualquier estudiante, El estudiante' - que algo se había destacado en pasadas agitaciones universitarias"' (186-7). Es simbólico y sorprendente el hecho de que sea el mismo estudiante quien no se reconozca con identidad propia. Carpentier logra crear la idea de que el hombre no moldea la posición política que ocupa, sino que la posición controla y termina dominando al individuo que la calza. El personaje llega a mitificarse como lo hicieron otros en obras de Valle Inclán y Miguel Angel Asturias entre tantos. El autor también borra las características físicas de este personaje. ${ }^{4}$ Es digno de notarse que este personaje del colegial va asumiendo ciertos rasgos que son los mismos que se le atribuyen al dictador, comenzando con la coincidencia de que ambos son de cuna humilde. El estudiante es huérfano de madre e hijo de un maestrillo de escuela; y el Primer Magistrado es hijo de un periodista pobretón y de provincia. ${ }^{5}$

Carpentier continua moldeando este personaje allanado del estudiante para reafirmar aun más el arquetipo. Al igual que todos los de su calaña, es casi irıposible el aprehenderle: "Estaba en la ciudad, sin embargo; pero cuando la policía irrumpía en sus escondrijos, sólo encontraban los agentes una cama desarreglada, con indicios de reciente presencia, una botella de cerveza a medio beber, papeles quemados, colillas de cigarros, un libro dejado en el piso. .." (187). O sea que el personaje asume un papel fantasmagórico, no es más que una sombra que deja entrever su silueta de vez en cuando. Llega a ser una idea que el pueblo adora y mitifica sin llegar a analizar las consecuencias que podría acarrear una mala selección. Es decir que mientras peor actue el dictador más van a sobresalir las pocas virtudes del estudiante, el mismo pueblo se engaña al ponerse una venda sobre los ojos. La masa exasperada por la constante lucha contra la tiranía, llega al extremo de buscar la salvación en cualquier mequetrefe que les haga promesas, sin darse cuenta que a veces todo es fútil y que la situación es irreversible. Crean una leyenda alrededor del estudiante, para hacerle ver como el cristo redentor del pueblo oprimido: "reformador combatiente, defensor de los pobres, enemigo de los ricos, azote de los corrompidos, recuperador de una nacionalidad alienada por el capitalismo, con antece- 
sores en varios caudillos populares de nuestras guerras de independencia..." (231). Es la fantasía del exaltado populacho que le va atribuyendo cualidades de Santo que sirven para ensanchar y fortificar este mito que se ha ido creando. El hombre de carne y hueso va desintegrándose ante los ojos del pueblo para convertirse en una leyenda viviente. Es obvio que el novelista al cincelar este personaje arquetípico quiere recopilar muy cuidadosamente todos los diferentes aspectos que tengan cabida, por eso que le presenta en los numerosos disfraces que usa para evadirse dentro de los diferentes planos en donde circula. $^{6}$

El pueblo es el bastión de donde brota la fuerza que sostiene al estudiante en la lucha contra la dictadura. Los combatientes idealistas que rinden sus vidas por la causa, son los que en realidad van alimentando al monstruo que sigue expandiéndose dentro de ese extraño ambiente: "trasladándose del Llano a la Montaña, de los puertos pesqueros a los aserraderos de Tierras Calientes, era el instigador, el organizador de todo aquello" (223-24). O sea que el estudiante ha pasado de un medio ambiente a otro, de la ciudad al campo, y es ahora que se le ve por primera vez como un creciente río que va arrollando todo lo que interceda en su camino. Es el que controla y manipula esas guerrillas que tan magnífico resultado le han dado a los movimientos revolucionarios dentro de la historia política de los pueblos.

Es necesario subrayar que el escritor triunfa en su intento de crear este arquetipo mediante la confrontación de los dos personajes centrales. Carpentier hace que estas dos figuras determinen ellos mismos el papel que desarrollan dentro de la sociedad: "Y se contemplaban ambos, el Amo, el Investido, el Inamovible, y el Débil, el Soterrado, el Utopista, por sobre el foso de dos generaciones, viéndose las carnes por primera vez... Era el de Arriba, para el de Abajo, un arquetipo, un ejemplar de histórica muestra, figura hecha para centrar algunos carteles, producto de un folklore...y era el de Abajo, para el de Arriba, otro personaje folklórico... Ambos habían salido de lo mismo" (234-35). Esta última frase lo resume todo, pues es la totalidad de dos personajes que se complementan, ambos son el principio y el fin que completan el círculo vicioso.

Desde el comienzo se ha visto que el escritor ha tratado de comunicar al lector, la vida metamorfósica del estudiante, personaje que llega a convertirse en un mito. El colegial idealista será la primera etapa del personaje que va evolucionando hasta el desarrollo completo de la figura pragmática del Primer Magistrado. Pudiendo concluirse que las diferencias básicas entre ambos hombres residen más en el desequilibrio del poder que en los principios que les rigen. Una vez que se estreche el desnivel que separa a las dos figuras que ha tallado el autor, surge un mismo individuo: el hombre poderoso. Esta idea la expresa el novelista muy explícitamente en el monólogo-diálogo que mantienen los dos personajes. Carpentier logra que las palabras rompan barreras, logrando que el lector se de cuenta que no puede separar a los dos personajes. Ambos son las dos perfectas mitades de la esfera total: una más rudimentaria, la otra más acabada. ${ }^{7}$

Finalmente, se puede concluir que el autor desde el relato viene proyectando la figura del estudiante que lucha para sobrevivir, dentro de la continua yuxtaposición que le ofrecen su cuerpo y su espíritu. Así pues, se desemboca en otra figura del estudiante que sigue la trayectoria que le llevará a la cima del poder temporal. No cabe duda que el 
estudiante del presente no es otro que el Primer Magistrado del futuro. Se va moldeando a lo largo de una marcada progresión que se opone a los principios morales, los cuales guiarán al hombre de la nada al poder y del poder a la nada.

Foreign Language Department

East Tennessee State University

\section{NOTAS}

${ }^{1}$ Alejo Carpentier, El camino de Santiago (Buenos Aires: Editorial Galerna, S. L., 1967). Se cita siempre por esta edición, con números arábigos entre paréntesis y en el texto.

${ }^{2}$ Se debe hacer hincapie en el enorme influjo que el agua ejerce sobre los personajes de Carpentier, y que a cada paso que ocurre un cambio espiritual en la figura central, este líquido está presente. Mircea Eliade ha estudiado la importancia y significación del agua en la obra de Carpentier en su libro El mito del eterno retorno (Madrid: Alianza Editorial, 1972), pp.80-2.

${ }^{3}$ Alejo Carpentier, El recurso del método (6a. ed., Madrid: Siglo XXI de España Editores, S. A., 1974), p. 231. Se cita sicmpre por esta edición y con números arábigos.

${ }^{4}$ Idem. "no acababan de ponerse de acuerdo los Expertos de la Seguridad sobre su aspecto físico, estatura, fisionomía, corpulencia. Decían unos que tenía los ojos verdes; decían otros que los tenía castaños; decían éstos que era atlético; decían aquellos que era hombre debilucho y enfermizo: 23 años, según los registros de inmatriculación universitaria; huérfano de madre; hijo de un maestrescuela caído en la matanza de Nueva Córdoba.” Pág. 187.

5 Idem. "donde le habían nacido sus hijos cuando, arrastrando la pobre vida del periodista provinciano, sólo podía of recer a los suyos, ciertos días, algún papelón de azúcar, para endulzar un hervido de plátanos y mendrugos, el único plato antes del sueño." Pág. 67.

${ }^{6}$ Idem. "corría por los tejados, saltaba de azotea en azotea, se disfrazaba de pastor protestante, de capuchino franciscano, ciego fingido un día, falso policía al otro - labriego, minero, arreador de recuas, médico con maletín, turista inglés, arpista ambulante, cargador de huacales ...” Pág. 231.

${ }^{7}$ Idem. "No sabe hasta que punto está en su papel/le falta dimensión, fuerza, para ser algo/ el arcángel que fuimos todos/ capaz de cualquier cosa: no tiene nada que perder/ es horrible pensar en eso, en eso/ su palabra no vale un carajo..." Pág. 236. 